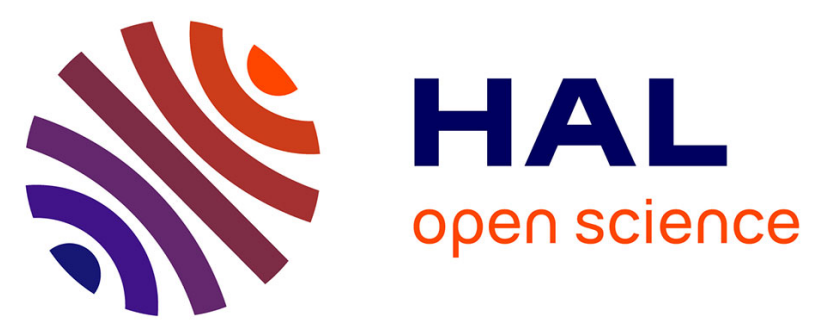

\title{
Oribatid mite (Acari: Oribatida) communities of urban brownfields in Tallinn, Estonia, and their potential as bioindicators of wasteland successional stage
} Piret Vacht, Helin Niglas, Annely Kuu, Tiiu Koff, Sander Kutti, Jane Raamets

\section{- To cite this version:}

Piret Vacht, Helin Niglas, Annely Kuu, Tiiu Koff, Sander Kutti, et al.. Oribatid mite (Acari: Oribatida) communities of urban brownfields in Tallinn, Estonia, and their potential as bioindicators of wasteland successional stage. Acarologia, 2019, 59 (1), pp.26-32. 10.24349/acarologia/20194310 . hal-01981490

\author{
HAL Id: hal-01981490 \\ https://hal.science/hal-01981490
}

Submitted on 15 Jan 2019

HAL is a multi-disciplinary open access archive for the deposit and dissemination of scientific research documents, whether they are published or not. The documents may come from teaching and research institutions in France or abroad, or from public or private research centers.
L'archive ouverte pluridisciplinaire HAL, est destinée au dépôt et à la diffusion de documents scientifiques de niveau recherche, publiés ou non, émanant des établissements d'enseignement et de recherche français ou étrangers, des laboratoires publics ou privés. 


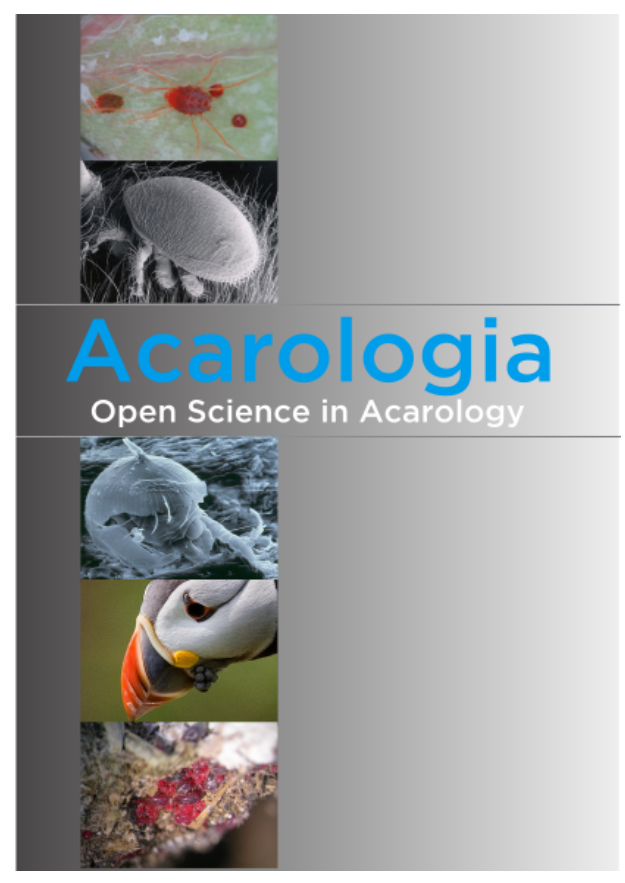

\section{Acarologia}

A quarterly journal of acarology, since 1959

Publishing on all aspects of the Acari

All information:

http://www1.montpellier.inra.fr/CBGP/acarologia/ acarologia@supagro.inra.fr

\section{OPEN ACCESS}

\section{Acarologia is proudly non-profit, with no page charges and free open access}

Please help us maintain this system by encouraging your institutes to subscribe to the print version of the journal and by sending us your high quality research on the Acari.

Subscriptions: Year 2019 (Volume 59): $450 €$ http://www1.montpellier.inra.fr/CBGP/acarologia/subscribe.php

Previous volumes (2010-2017): $250 €$ / year (4 issues)

Acarologia, CBGP, CS 30016, 34988 MONTFERRIER-sur-LEZ Cedex, France

The digitalization of Acarologia papers prior to 2000 was supported by Agropolis Fondation under the reference ID 1500-024 through the « Investissements d'avenir » programme

(Labex Agro: ANR-10-LABX-0001-01)
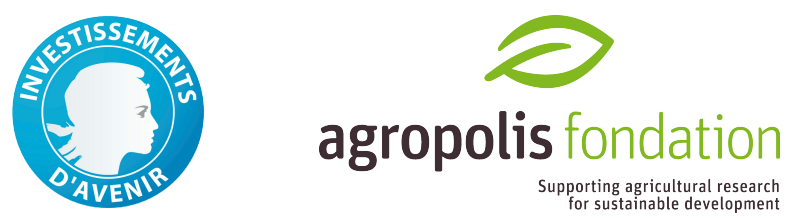

Acarologia is under free license and distributed under the terms of the

Creative Commons-BY-NC-ND which permits unrestricted non-commercial use, distribution, and reproduction in any medium, provided the original author and source are credited. 


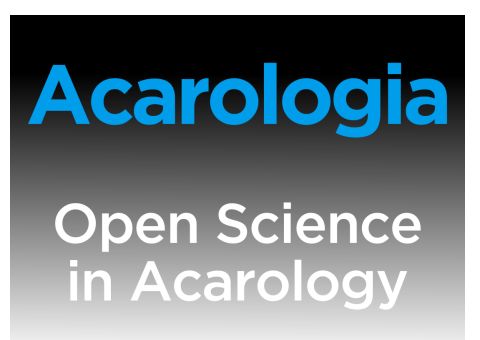

Oribatid mite (Acari: Oribatida)

communities of urban brownfields in Tallinn, Estonia, and their potential as bioindicators of wasteland successional stage

\author{
Piret Vacht ${ }^{a}$, Helin Niglas ${ }^{a}$, Annely Kuu ${ }^{b}$, Tiiu Koff ${ }^{a, c}$, Sander Kutti ${ }^{b}$, Jane \\ Raamets $^{b}$ \\ ${ }^{a}$ School of Natural Sciences and Health, Tallinn University, Narva Rd 25, 10120, Tallinn, Estonia. \\ ${ }^{b}$ School of Engineering, Tartu College of Tallinn University of Technology, Puiestee 78, 51008, Tartu, \\ Estonia. \\ ${ }^{c}$ Institute of Ecology, Tallinn University, Uus-Sadama 5, 10120, Tallinn, Estonia.
}

\section{Original article}

\section{ABSTRACT}

Urban brownfields are ecologically valuable ecosystems that have been and are under various anthropogenic influences. Because brownfields are subject to rapid development in urban areas, their biological communities, including soil mesofauna, are overlooked and seldom researched, even though they could provide valuable insight into the ecological functioning of these areas. This exploratory study describes the community characteristics of oribatid mite fauna of 12 brownfields in Tallinn, Estonia, and analyzes the potential of oribatid mites as bioindicators of brownfield successional stage. This study provides the first faunistic list of oribatid mites from the brownfields of Tallinn. No significant changes in species abundance or richness depending on the successional stage were discovered. While some changes in community structure were noted, due to low overall abundance, no clear indicators of brownfield successional stage were identified. For future research on urban brownfield oribatid fauna with the intention of finding potential bioindicators of brownfield properties, increasing the sampling size and inclusion of other groups of soil mesofauna is recommended.
Received 07 July 2018

Accepted 06 January 2019

Published 15 January 2019

Corresponding author

Piret Vacht: piret.vacht@tlu.ee

Academic editor

Ekaterina Sidorchuk

\section{DOI}

10.24349/acarologia/20194310

\section{Copyright}

Vacht et al.

Distributed under

Creative Commons CC-BY 4.0
Keywords brownfields; wastelands; Oribatida; bioindication; technosol

\section{Introduction}

Urban brownfields, also known as wastelands (Atkinson et al. 2014; Mathey et al. 2018) are areas that have been under development in past, but have not been in formal use since (CABERNET 2006; Siebielec et al. 2012). The term often implies that the area is affected by contamination (CABERNET 2006; Mathey et al. 2018), however, this is not always the situation depending on the characteristics of previous use. Detailed information about the history of these areas is, however, not always available. This makes decision making about future developments of the urban brownfields challenging.

In Tallinn, Estonia, wastelands make up about 7\% of the city area (Karro-Kalberg 2011). These areas are often considered as vacant space in cities and are therefore under rapid changes, including consturction and road development, due to the current urban processes. Wastelands are ecologically important urban green spaces that offer various ecosystem services, including habitats for miscellaneous fauna and flora (Herbst and Herbst 2006; Strauss and Biedermann 2006; Pueffel et al. 2018). 
Previous studies have shown that microarthropods are one of the first groups of soil biota to inhabit novel areas (Hågvar et al. 2009; Hågvar 2012). However the communities tend to be more species-rich in older soils, influenced positively by the presence of vegetation (Madej et al. 2011; Wissuwa et al. 2012). Oribatid mites (Acari: Oribatida) are known as indicators of soil properties (Steiner 1995; Behan-Pelletier 1999; Magro et al. 2013), but they are not often researched in harsh environments such as urban wasteland Technosols (Madej et al. 2011; Rumble et al. 2018). The former use of wastelands may also affect the soil conditions and therefore influence the soil biota, including oribatid mite communities (Zaitsev and Straalen 2001). There are few studies addressing the soil acarofauna of urban areas (Weigmann and Jung 1992; Eitminavičiūtè 2006a, b; Minor and Cianciolo 2007). In Estonia, soil oribatid mites communities have so far not been studied in urban areas, only data from some coastal areas (Eitminavičiūtè 1976), coniferous forest riparian zones (Vacht et al. 2014) and Estonian airfields (Vacht et al. In Press) have been published. Because soil biota, including microarthropods, play an important part in major soil processes and functions, their presence or absence and diversity should be monitored in order to gain knowledge about the stability and functioning of these areas. Therefore, it is important to map what kind of soil biological communities can be found in urban brownfields of Tallinn and whether these can be used as bioindicators helping to evaluate the ecological importance of these areas.

The aim of this explorative study was (1) to characterize the oribatid mite communities (community structure, species richness, evenness and diversity) of various urban wastelands in Tallinn that differ in their properties, past usage and successional stage; (2) to find out whether oribatid mites are suitable bioindicators of wasteland successonal stage.

\section{Methods}

Sampling from 12 urban brownfields in Tallinn, Estonia, was conducted in September 2014 and September 2015. Each year four samples were collected from each study area. Table 1 shows the locations and characteristics of the sampling sites. The study areas included in this study have been out of formal use for up to 50 years, classifying into the three youngest (I, II and III) successional stages distinguished by Mathey and Rink (2010), that do not yet have high and dense vegetation cover. Samples were collected using ø $5 \mathrm{~cm}$ soil auger $(0-10 \mathrm{~cm}$ of topsoil, in total $196 \mathrm{~cm}^{3}$ ) from sampling sites most characteristic to the wasteland. Because this was an exploratory study, samples for soil chemical analyses were collected from each site and pooled, for general background information without aim to link them directly to the soil biological communities. Soil organic matter and carbonate content was analyzed using prepASH® 340 at Tallinn University Institute of Ecology, soil P, K, Ca and Mg content were analyzed, and $\mathrm{pH}_{\mathrm{KCl}}$ measured using standard methods at the Estonian Agricultural Research Center.

Microarthropods were extracted using Berlese-Tullgren funnel until samples were fully dry (minimum of 72 hours) and stored in $90 \%$ ethanol. For clearing purposes $80 \%$ lactic acid was used on oribatid mites. Samples $(\mathrm{N}=96)$ were hand sorted, oribatid mites identified (Weigmann 2006; Niedbała 2008)and counted using cavity slides on light microscope Olympus BX51 at 200-600 × magnification. The nomenclature follows Weigmann (2006). Samples have been deposited at Tallinn University Institute of Ecology. The oribatid mite species data from two years were pooled for numerical analysis.

Community parameter calculations were conducted using $\mathrm{R}$ programming environment (R Development Core Team 2014) using 'vegan' package (Oksanen 2018). Due to very low abundance of oribatid mites in the samples multivariate community analysis could not be applied. 
Table 1 Study area characteristics, including coordinates, site successional stage (Mathey and Rink 2010) classification (I refering sites less than 3 year old, II to sites 3 to 10 years old, III to sites 10 to 50 years old) and short description of site purpose or previous use and vegetation characteristics.

\begin{tabular}{|c|c|c|c|c|}
\hline & & \multicolumn{3}{|r|}{ Characteristics } \\
\hline $\begin{array}{l}\text { Sampling } \\
\text { site } \\
\text { symbol }\end{array}$ & Coordinates & $\begin{array}{c}\text { Successional } \\
\text { stage }\end{array}$ & Site description & Characteristic vascular plants \\
\hline $\mathrm{L}$ & $\begin{array}{l}\text { N 592 } 24^{\prime} 55.33^{\prime \prime} \\
\text { E } 24^{\circ} 52^{\prime} 8.79^{\prime \prime}\end{array}$ & I & $\begin{array}{l}\text { Former urban } \\
\text { agriculture site, } \\
\text { near airfield }\end{array}$ & $\begin{array}{l}\text { Achillea millefolium, Arctium tomentosum, } \\
\text { Artemisia vulgaris, Atriplex patula, Cirsium } \\
\text { arvense, Echium vulgare, Scorzonera humilis, } \\
\text { Trifolium medium, Tussilago farfara, Urtica dioica, } \\
\text { Verbascum nigrum }\end{array}$ \\
\hline $\mathrm{F}$ & $\begin{array}{l}\text { N } 59^{\circ} 25^{\prime} 8.81^{\prime \prime} \\
\text { E } 24^{\circ} 45^{\prime} 28.3^{\prime \prime}\end{array}$ & I & $\begin{array}{l}\text { Illegal garbage } \\
\text { dump, construction } \\
\text { waste }\end{array}$ & $\begin{array}{l}\text { Arctium tomentosum, Artemisia vulgaris, Atriplex } \\
\text { patula, Betula pendula, Cirsium vulgare, Epilobium } \\
\text { angustifolium, Melilotus officinalis, Salix spp, } \\
\text { Tanacetum vulgare }\end{array}$ \\
\hline $\mathrm{P}$ & $\begin{array}{l}\text { N 592ㄱ'3.49" } \\
\text { E } 24^{\circ} 49^{\prime} 11.27^{\prime \prime}\end{array}$ & II & $\begin{array}{l}\text { Construction site, } \\
\text { construction waste }\end{array}$ & $\begin{array}{l}\text { Acer platanoides, Achillea millefolium, Alchemilla } \\
\text { vulgaris, Poaceae, Polygala vulgaris, Rosa spp, } \\
\text { Scorzonera humilis, Taraxacum officinale, Tussilago } \\
\text { farfara, Sorbus aucuparia }\end{array}$ \\
\hline $\mathrm{V}$ & $\begin{array}{l}\text { N } 59^{\circ} 25^{\prime} 18.32^{\prime \prime} \\
\text { E } 24^{\circ} 44^{\prime} 58.84^{\prime \prime}\end{array}$ & II & $\begin{array}{l}\text { Former timber mill } \\
\text { factory site }\end{array}$ & $\begin{array}{l}\text { Acer platanoides, Anchusa officinalis, Betula } \\
\text { pendula, Fraxinus excelsior, Poaceae, Populus } \\
\text { tremula, Salix spp }\end{array}$ \\
\hline M & $\begin{array}{l}\text { N } 59^{\circ} 25^{\prime} 51.42^{\prime \prime} \\
\text { E } 24^{\circ} 40^{\prime} 58.3^{\prime \prime}\end{array}$ & III & Snow-melting site & $\begin{array}{l}\text { Acer platanoides, Achillea millefolium, Melilotus } \\
\text { albus , Phragmites australis , Plantago major, Salix } \\
\text { spp, Solidago virgaurea, Taraxacum officinale, } \\
\text { Tussilago farfara }\end{array}$ \\
\hline$S$ & $\begin{array}{l}\text { N } 59^{\circ} 25^{\prime} 11.98^{\prime \prime} \\
\text { E } 24^{\circ} 37^{\prime} 23.31^{\prime \prime}\end{array}$ & III & $\begin{array}{l}\text { Semi-natural area } \\
\text { with illegal garbage } \\
\text { dump }\end{array}$ & $\begin{array}{l}\text { Achillea millefolium, Artemisia vulgaris, Alnus } \\
\text { incana, Poaceae, Populus tremula, Ribes nigrum, } \\
\text { Solidago virgaurea, Taraxacum officinale }\end{array}$ \\
\hline $\mathrm{R}$ & $\begin{array}{l}\text { N } 59^{\circ} 24^{\prime} 50.61^{\prime \prime} \\
\text { E } 24^{\circ} 39^{\prime} 41.89^{\prime \prime}\end{array}$ & III & Construction waste & $\begin{array}{l}\text { Aegopodium podagraria, Angelica sylvestris, } \\
\text { Artemisia vulgaris, Rubus idaeus, Rumex } \\
\text { obtusifolius, Urtica dioica }\end{array}$ \\
\hline A & $\begin{array}{l}\text { N } 59^{\circ} 27^{\prime} 19.43^{\prime \prime} \\
\text { E } 24^{\circ} 41^{\prime} 45.21^{\prime \prime}\end{array}$ & III & $\begin{array}{l}\text { Railway side, no } \\
\text { longer in use }\end{array}$ & $\begin{array}{l}\text { Aegopodium podagraria, Convolvulus arvensis, } \\
\text { Equisetum pratense, Phragmites australis , Salix } \\
\text { spp, Urtica dioica }\end{array}$ \\
\hline $\mathrm{T}$ & $\begin{array}{l}\text { N } 59^{\circ} 27^{\prime} 0.06^{\prime \prime} \\
\text { E } 24^{\circ} 43^{\prime} 12.38^{\prime \prime}\end{array}$ & III & $\begin{array}{l}\text { Railway side, in } \\
\text { infrequent use }\end{array}$ & $\begin{array}{l}\text { Achillea millefolium, Aegopodium podagraria, } \\
\text { Fraxinus excelsior, Medicago falcata, Poaceae, } \\
\text { Rumex obtusifolius, Salix spp, Sedum acre }\end{array}$ \\
\hline K & $\begin{array}{l}\text { N } 59^{\circ} 26^{\prime} 56.23^{\prime \prime} \\
\text { E } 24^{\circ} 44^{\prime} 38.91^{\prime \prime}\end{array}$ & III & $\begin{array}{l}\text { Construction site, } \\
\text { contruction waste }\end{array}$ & $\begin{array}{l}\text { Acer platanoides, Arctium tomentosum, Artemisia } \\
\text { absinthium, Bunias orientalis, Salix spp, Saponaria } \\
\text { officinalis }\end{array}$ \\
\hline $\mathrm{U}$ & $\begin{array}{l}\text { N } 59^{\circ} 26^{\prime} 26.35^{\prime \prime} \\
\text { E } 24^{\circ} 46^{\prime} 7.02^{\prime \prime}\end{array}$ & III & $\begin{array}{l}\text { Construction site, } \\
\text { former harbour } \\
\text { warehouse site }\end{array}$ & $\begin{array}{l}\text { Alnus incana, Artemisia absinthium, Chelidonium } \\
\text { majus, Impatiens parviflora, Populus tremula, Salix } \\
\text { spp, Taraxacum officinale }\end{array}$ \\
\hline$x$ & $\begin{array}{l}\text { N } 59^{\circ} 26^{\prime} 48.93^{\prime \prime} \\
\text { E } 24^{\circ} 50^{\prime} 15.17^{\prime \prime}\end{array}$ & III & $\begin{array}{l}\text { Former military } \\
\text { airfield, } \\
\text { construction waste }\end{array}$ & $\begin{array}{l}\text { Artemisia absinthium, Chrysosplenium } \\
\text { alternifolium, Lamium album, Salix spp, } \\
\text { Symphoricarpos albus, Ulmus glabra }\end{array}$ \\
\hline
\end{tabular}




\section{Results and discussion}

The studied wasteland soils can be classified as Technosols due to the high volume of anthropogenic artifacts, mostly construction waste, found in them. The amount of anthropogenic deposits in the studied soils together their low organic matter content (Table 2) refers to their low water holding capacity, which can be considered unfavorable habitat characteristics for most soil mesofauna. Urban soils in Tallinn have generally neutral to mildly alkaline $\mathrm{pH}$, which was confirmed by the results. Some study areas stood out by notably higher phosphorus or potassium content. Table 2 shows the results of the soil chemical analysis. From 96 samples 300 oribatid mites were identified. The abundance of oribatid mites differed greatly between the study sites. Even after pooling the data from two years the abundance per brownfield $(\mathrm{N}=8)$ varied from just one individual found in $\mathrm{K}$ and $\mathrm{A}$ sites to $34-42$ individuals at $\mathrm{P}, \mathrm{V}$ and $\mathrm{X}$ sites. Even though the youngest successional stage had lower oribatid mite abundance than stages II and III, these older stages (II and III) also had sites with only one individual.

In total 17 species were encountered. The species list with abundance data $(\mathrm{N}=8)$ is shown in Table 3. Highest diversity (Shannon's H) was encountered in the study area F $(\mathrm{H}=1.8)$, followed by the site $\mathrm{P}(\mathrm{H}=1.7)$ and site $\mathrm{V}(\mathrm{H}=1.4)$. Community evenness was highest in the study areas $\mathrm{R}, \mathrm{T}$ and $\mathrm{F}$ (1.0, 0.9 and 0.9 respectively). Species richness did not increase with increasing successional stage.

Some changes in species composition with increasing successional stage were noted. For example, while Platynothrus peltifer C. L. Koch, 1839 was the species encountered only on a site belonging to the youngest successional stage (only represented by two individuals), most species that were present at stage I were also encountered at the older successional stages. The slowly reproducing $P$. peltifer is known to be more abundant in near-neutral to alkaline soil conditions (van Straalen and Verhoef 1997) and sensitive to heavy metals (Khalil et al. 2009). The presence of this species in urban wasteland ecosystem together with the species' known bioindicator properties is a promising combination for further studies. Eupelops torulosus C. L. Koch, 1939 and Trichoribates novus Sellnick, 1928 were only present at stages II and III. Both of these species are known to inhabit soils that already have vegetation $-E$. torulosus is often found in forest ecosystems (Siira-Pietikäinen et al. 2008; Vacht et al. 2018), T. novus in urban lawns (Weigmann and Kratz, 1987). Several species were indifferent to the successional stage of the wasteland (e.g Galumna lanceata Oudemans, 1900, Rhysotritia ardua C.L. Koch, 1841, Tectocepheus velatus velatus Knülle, 1954). All of these species are frequently encountered in urban and other human influenced ecosystems (Zaitsev and Straalen 2001; Caruso and Migliorini 2006; Eitminavičiūtè 2006b; Minor and Cianciolo 2007; Ivan and Vasiliu 2009;

Table 2 Results of soil chemical analysis to give an overview of wasteland soil conditions.

\begin{tabular}{cccccccc}
\hline & \multicolumn{7}{c}{ Soil parameters } \\
\hline $\begin{array}{c}\text { Sampling } \\
\text { site symbol }\end{array}$ & $\mathrm{pH}_{\mathrm{KCl}}$ & $\mathrm{P}(\mathrm{mg} / \mathrm{kg})$ & $\mathrm{K}(\mathrm{mg} / \mathrm{kg})$ & $\mathrm{Ca}(\mathrm{mg} / \mathrm{kg})$ & $\mathrm{Mg}(\mathrm{mg} / \mathrm{kg})$ & $\begin{array}{c}\text { Organic } \\
\text { matter }(\%)\end{array}$ & $\begin{array}{c}\text { Carbonates } \\
(\%)\end{array}$ \\
\hline $\mathrm{L}$ & 7.3 & 48 & 126 & 7837 & 202 & 2.7 & 8.7 \\
$\mathrm{~F}$ & 7.6 & 41 & 243 & 12800 & 286 & 4.8 & 16.4 \\
$\mathrm{P}$ & 7.6 & 51 & 143 & 6555 & 175 & 11.0 & 38.8 \\
$\mathrm{~V}$ & 7.6 & 74 & 220 & 6131 & 219 & 9.7 & 8.6 \\
$\mathrm{M}$ & 7.6 & 31 & 82 & 8968 & 128 & 4.9 & 11.4 \\
$\mathrm{~S}$ & 7.0 & 109 & 114 & 2761 & 99 & 4.5 & 0.5 \\
$\mathrm{R}$ & 7.4 & 95 & 140 & 4040 & 138 & 6.2 & 2.3 \\
$\mathrm{~A}$ & 7.3 & 17 & 729 & 4010 & 129 & 8.0 & 3.1 \\
$\mathrm{~T}$ & 7.3 & 78 & 172 & 5714 & 211 & 8.3 & 3.0 \\
$\mathrm{~K}$ & 7.1 & 302 & 267 & 6312 & 232 & 10.9 & 16.0 \\
$\mathrm{U}$ & 7.2 & 206 & 213 & 5723 & 228 & 5.1 & 9.8 \\
$\mathrm{X}$ & 7.3 & 46 & 286 & 11320 & 197 & 14.8 & 23.2 \\
\hline
\end{tabular}


Table 3 Species list and number of specimens collected from the study area (total N=96, each count is based on data from 8 samples of $196 \mathrm{~cm}^{3}$ of soil).

\begin{tabular}{|c|c|c|c|c|c|c|c|c|c|c|c|c|}
\hline \multirow[b]{3}{*}{ Species } & \multicolumn{12}{|c|}{ Sampling sites and successional stage } \\
\hline & \multicolumn{2}{|c|}{$\mathrm{I}$} & \multicolumn{2}{|c|}{ II } & \multicolumn{8}{|c|}{ III } \\
\hline & $\mathrm{L}$ & F & $\mathrm{P}$ & $\mathrm{V}$ & $\mathrm{M}$ & $S$ & $\mathrm{R}$ & $\mathrm{A}$ & $\mathrm{T}$ & $\mathrm{K}$ & $\bar{U}$ & $X$ \\
\hline Rysotritia ardua (Koch, 1841) & - & 2 & - & 1 & - & - & - & - & - & - & - & 1 \\
\hline Trhypochthonius spp (Berlese, 1904) & - & - & - & 1 & - & - & - & - & - & - & - & - \\
\hline Platynothrus peltifer (Koch, 1839) & - & 2 & - & - & - & - & - & - & - & - & - & - \\
\hline Hermannia convexa (Koch, 1839) & - & - & - & 1 & - & - & - & - & - & - & - & - \\
\hline Tectocepheus velatus velatus (Michael, 1880) & - & 1 & - & 2 & - & - & 2 & - & - & - & - & - \\
\hline Scutovertex minutus (Koch, 1835) & - & - & 1 & - & - & - & - & - & - & - & - & - \\
\hline Eupelops torulosus (Koch, 1839) & - & - & 2 & 1 & - & 1 & 1 & - & - & - & 1 & 4 \\
\hline Eupelops hygrophilus (Knülle, 1954) & - & 3 & 4 & - & - & - & 1 & - & 2 & - & - & 1 \\
\hline Achipteria coleoptrata (Linnaeus, 1758) & - & 2 & 3 & 21 & 4 & - & - & 1 & 3 & - & - & - \\
\hline Achipteria nitens (Nicolet, 1855) & - & - & 1 & 7 & - & - & - & - & - & - & - & - \\
\hline Achipteria sellnicki (van der Hammen, 1952) & - & 1 & - & - & - & - & - & - & - & 1 & 1 & - \\
\hline Scheloribates laevigatus (Koch, 1836) & 1 & 5 & 16 & - & - & - & - & - & - & - & - & 31 \\
\hline Chamobates voigtsi (Oudemans, 1902) & - & - & 3 & 2 & - & - & - & - & - & - & - & - \\
\hline Ceratozetes minutissimus (Willmann, 1951) & - & - & - & - & - & - & - & - & - & - & - & 1 \\
\hline Trichoribates novus (Sellnick, 1928) & - & - & - & 1 & - & - & 1 & - & - & - & - & 2 \\
\hline Mycobates tridactylus (Willmann, 1929) & - & - & 1 & - & - & - & - & - & - & - & - & - \\
\hline Galumna lanceata (Oudemans, 1900) & 1 & - & 3 & - & - & - & - & - & 1 & - & - & 2 \\
\hline
\end{tabular}

Vacht et al. 2018), for example, T. velatus velatus is often one of the most abundant species in urban ecosystems (Eitminavičiūtè 2006b; Minor and Cianciolo 2007).

The number of individuals encountered in this study was very low compared to our previous research from areas under anthropogenic influences (Vacht et al. 2018; Vacht et al. In Press) and not sufficient for determining the full potential of oribatid mites as bioindicators of brownfield properties, including changes in community patterns in relation to successional stage, therefore this study is unable to recommend using oribatid mites alone as indicators of wasteland properties, including successonal stage. Increasing the sampling size and combining the results with other organism groups (e.g. Collembola, Mesostigmata) should be considered.

\section{Conclusion}

Due to high concentration of anthropogenic imputs and low organic matter content, urban wasteland Technosols encountered in this study, are very poor habitats for oribatid mites, resulting in low abundance and diversity. This study provided novel species data on brownfield oribatid mite communities in Tallinn, Estonia. In comparison of three successional stages no significant changes were detected in abundance or diversity of the communities, but some changes in community structure were noted. Due to the low total abundance of oribatid mites, further studies are required to test, whether oribatid mites can be used as indicators of successional stage in urban brownfields. In future studies in urban brownfields we recommend increasing the sampling size. In order to assess the ecological functioning of the areas, the bioindicative data from their oribatid mite communities should be combined with that from the other groups of soil mesofauna.

\section{Acknowledgements}

We are grateful for financial support from Tallinn University's Centre of Excellence initiatives "Studies of natural and man-made environments" and "Natural Sciences and Sustainable Development", and also Tallinn University's Student Research Project Grant. 


\section{References}

Atkinson G., Doick K.J., Burningham K., France C. 2014. Brownfield regeneration to greenspace: delivery of project objectives for social and environmental gain. Urban For. Urban Green., 13(3): 586-594. doi:10.1016/j.ufug.2013.04.002

Behan-Pelletier V.M. 1999. Oribatid mite biodiversity in agroecosystems : role for bioindication. Agric. Ecosyst. Environ., 74: 411-423. doi:10.1016/s0167-8809(99)00046-8

CABERNET. 2006. Sustainable Brownfield Regeneration: CABERNET Network Report. University of Nottingham, Nottingham.

Caruso T., Migliorini M. 2006. Micro-arthropod communities under human disturbance: is taxonomic aggregation a valuable tool for detecting multivariate change? Evidence from Mediterranean soil oribatid coenoses. Acta Oecologica, 30(1): 46-53. doi:10.1016/j.actao.2006.01.003

Eitminavičiūte I. 1976. Soil invertebrate fauna of the coastal area in the East Baltic region. Vilnius: Academy of Sciences of the Lithuanian SSR, Leidykla Mokslas. pp 172.

Eitminavičiūtė I. 2006a. Microarthropod communities in anthropogenic urban soils. 1. Structure of microarthropod complexes in soils of roadside lawns. Entomol. Rev., 86(S2): S128-S135. doi:10.1134/S0013873806110029

Eitminavičiūtė I. 2006b. Microarthropod communities in anthropogenic urban soils. 2. Seasonal dynamics of microarthropod abundance in soils at roundabout junctions. Entomol. Rev., 86(S2): S136-S146. doi:10.1134/S0013873806110030

Hågvar S. 2012. Primary succession in glacier forelands: How small animals conquer new land around melting glaciers. In: Young S., Silvern S. (Eds) Int. Perspect. Glob. Environ. Chang., Rijeka: InTech. pp. 151-172. doi:10.5772/26536

Hågvar S., Solhøy T., Mong C. 2009. Primary succession of soil mites (Acari) in a Norwegian glacier foreland, with emphasis on Oribatid species. Arctic, Antarct. Alp. Res., 41: $219-227$. doi:10.1657/1938-4246-41.2.219

Herbst H., Herbst V. 2006. The development of an evaluation method using a geographic information system to determine the importance of wasteland sites as urban wildlife areas. Landsc. Urban Plan., 77(1-2): 178-195. doi:10.1016/j.landurbplan.2005.02.005

Ivan O., Vasiliu A. 2009. Oribatid mites (Acari, Oribatida) - Bioindicators of forest soils pollution with heavy metals and fluorine. Ann. For. Res., 52(1): 11-18.

Karro-Kalberg M. 2011. Plaan B. Tühermaade regenereerimine [MA Thesis]. Tallinn: Estonian Academy of Arts. p. 97.

Khalil M., Janssens T., Berg M., van Straalen N.M. 2009. Identification of metal-responsive oribatid mites in a comparative survey of polluted soil. Pedobiologia, 52: 207-221. doi:10.1016/j.pedobi.2008.10.002

Madej G., Barczyk G., Gdawiec M. 2011. Evaluation of soil biological quality Index (QBS-ar): Its sensitivity and usefulness in the post-mining chronosequence - Preliminary research. Polish J. Environ. Stud., 20(5): 1367-1372.

Magro S., Gutiérrez-López M., Casado M.A., Jiménez M.D., Trigo D., Mola I., Balaguer L. 2013. Soil functionality at the roadside: Zooming in on a microarthropod community in an anthropogenic soil. Ecol. Eng., 60: 81-87. doi:10.1016/j.ecoleng.2013.07.061

Mathey J., Arndt T., Banse J., Rink D. 2018. Public perception of spontaneous vegetation on brownfields in urban areas-Results from surveys in Dresden and Leipzig (Germany). Urban For. Urban Green., 29: 384-392. doi:10.1016/j.ufug.2016.10.007

Mathey J., Rink D. 2010. Urban wastelands - a chance for biodiversity in cities? Ecological aspects, social perceptions and acceptance of wilderness by residents. In: Muller N., Werner P., Kelcey J. G. (Eds) Urban Biodivers. Des., Oxford: Wiley-Blackwell. pp. 406-424. doi:10.1002/9781444318654.ch21

Minor M.A., Cianciolo J.M. 2007. Diversity of soil mites (Acari: Oribatida, Mesostigmata) along a gradient of land use types in New York. Appl. Soil Ecol., 35(1): 140-153. doi:10.1016/j.apsoil.2006.05. 004

Niedbała W. 2008. Ptyctimous mites (Acari: Oribatida) of Poland - 3rd ed. Iwan D., Makol J. (Eds) Warsaw: Natura optima dux Foundation. pp. 242.

Oksanen J. 2018. Vegan: ecological diversity. R Package. Version 2.4-4, 11.

Pueffel C., Haase D., Priess J.A. 2018. Mapping ecosystem services on brownfields in Leipzig, Germany. Ecosyst. Serv., 30: 73-85. doi:10.1016/j.ecoser.2018.01.011

R Development Core Team. R: A language and environment for statistical computing. R Foundation for Statistical Computing [Internet]. [07 December 2018]. Available from: http://www.rproject.org

Rumble H., Finch P., Gange A. 2018. Green roof soil organisms: anthropogenic assemblages or natural communities? Appl. Soil Ecol., 126: 11-20. doi:10.1016/j.apsoil.2018.01.010

Siebielec G., Rabl-Berger S., Bluemlein P., Schweiker M., Huber S., Wieshofer I., Biasioli M., Marsan F.A., Medved P., Sobocka J., Galuskova I., Vokurkova P. 2012. Brownfield redevelopment as an alternative to greenfield consumption in urban development in Central Europe. Urban SMS Soil Manag. Strateg., No. 6.1.3: 1-24.

Siira-Pietikäinen, A., Penttinen, R., Huhta, V. 2008. Oribatid mites (Acari: Oribatida) in boreal forest floor and decaying wood. Pedobiologia, 52: 111-118. doi:10.1016/j.pedobi.2008.05.001

Steiner W.A. 1995. Influence of air pollution on moss-dwelling animals: 3. Terrestrial fauna, with emphasis on Oribatida and Collembola. Acarologia, 36(2): 149-173.

van Straalen N.M., Verhoef H. 1997. The development of a bioindicator system for soil acidity based on arthropod pH preferences. J. Appl. Ecol., 34: 217. doi:10.2307/2404860

Strauss B., Biedermann R. 2006. Urban brownfields as temporary habitats: driving forces for the diversity of phytophagous insects. Ecography (Cop.)., 29: 928-940. 
Vacht P., Puusepp L., Koff T., Reitalu T. 2014. Variability of riparian soil diatom communities and their potential as indicators of anthropogenic disturbances. Est. J. Ecol., 63: 168-184. doi:10.3176/eco.2014. 3.04

Vacht P., Puusepp L., Koff T. 2018. The use of oribatid mites and diatoms as combined indicators of contaminations from multiple origins in riparian zone forest soils in Estonia. Balt. For., 24(1): 24-35.

Vacht P., Kuu A., Puusepp L., Koff T., Kutti S., Raamets J., Küttim L. XXXX. Diatom and microarthropod communities of three airfields in Estonia - their differences and similarities and possible linkages to airfield properties. Eur. J. Ecol., X: XX-XX (In Press).

Weigmann G. 2006. Hornmilben (Oribatida). Die Tierwelt Deutschlands 76. Teil - Keltern: Goecke \& Evers, Keltern. pp. 520

Weigmann G., Jung E. 1992. Die Hornmilben (Acari, Oribatida) an Strassenbäumen in Stadtzonen unterschiedlicher Luftbelastnung in Berlin. Zool. Beiträge, 34: 273-287.

Weigmann, G., Kratz, W. 1987. Oribatid mites in urban zones of West Berlin. Biol. Fertil. Soils, 3: 81-84. doi:10.1007/BF00260583

Wissuwa J., Salamon J.A., Frank T. 2012. Effects of habitat age and plant species on predatory mites (Acari, Mesostigmata) in grassy arable fallows in Eastern Austria. Soil Biol. Biochem., 50: 96-107. doi:10.1016/j.soilbio.2012.02.025

Zaitsev A.S., Straalen N.M. Van 2001. Species diversity and metal accumulation in oribatid mites (Acari, Oribatida) of forests affected by a metallurgical plant. Pedobiologia., 45: 467-479. doi.org/10.1078/0031-4056-00100 